\title{
ПОРІВНЯЛЬНА ОЦІНКА МОЛОЧНОЇ ПРОДУКТИВНОСТІ КОРІВ УКРАЇНСЬКОЇ БУРОЇ МОЛОЧНОЇ ПОРОДИ PIЗНИХ ГЕНОТИПІВ ЗА ß-КАЗЁ̈НОМ
}

\author{
Ладика Володимир Іванович \\ доктор сільськогосподарських наук, професор, академік НААН України \\ Сумський національний аграрний університет \\ ORCID: 0000-0001-6748-7616 \\ E-mail:v.i.ladyka@ukr.net
}

Скляренко Юрій Іванович

доктор сільськогосподарських наук, ст.н.с. Інститут сільського господарства Північного Сходу НААН

ORCID: 0000-0002-6579-2382

E-mail: sklyrenk09753@ukr.net

Павленко Юлія Миколаївна

кандидат сільськогосподарських наук, доцент Сумський національний аграрний університет

ORCID: 0000-0002-4128-122X

E-mail: jasjulia@ukr.net

Малікова Альона Іванівна аспірант спеціальності 204-ТВППТ

Сумський національний аграрний університет

ORCID: 0000-0002-4277-0172

E-mail: lelikunique2@gmail.com

В останні роки суттєво зросли вимоги до якості молочної продукції, що у свою чергу вимагає використання в селекиї генетичних маркерів і пошуку їхнього зв'язку з молочною продуктивністю тварин. Дослідження впливу генотипу корів української бурої молочної породи за бета-казеїном на показники їхньої молочної продуктивності проводили в племінному заводі Державного підприємства «Дослідне господарство Інституту сільського господарства Північного Сходу НААН» Сумського району, Сумської області на поголів"ї української бурої молочної породи. Визначення поліморфрізму гена бетаказеїну проводили в генетичній лабораторії Інституту фізіології ім. Богомольия НАН. Молочну продуктивність визначали за щомісячними контрольними доїннями. Вміст жиру та білку в молоці визначали у лабораторії Інституту тваринництва НАAН на обладнанні фірми Bently. Тварини з генотипом A1A2 та A2A2 становили майже 90\% досліджуваного поголів'я. За результатами досліджень нами встановлено, що тварини з бажаним генотипом $A 2 A 2$ не поступаються за величиною надою тваринам з гетерозиготним генотипом A1A2 та гомозиготним - A1A1 як за першою, третьою, так і кращою лактаціями. За першою та кращою лактацією за вмістом жиру в молоці тварини з генотипом A2A2 поступалися тваринам інших досліджуваних генотипів, а за вмістом білка в молоці переважали їх. За кількістю молочного жиру корови з бажаним генотипом A2A2 поступалися тваринам з іншими генотипами за першою лактацією, але переважали їх за кількістю молочного білка. За кращою лактацією тварини з генотипом A2A2 переважали інших як за кількістю молочного жиру так $i$ білка. Отримані результати підтверджують раніше отримані нами результати, що використання бугаїв-плідників з генотипом бета-казеїну А2А2 має покращувати господарсько-корисні ознаки нащадків, порівняно з бугаями інших генотипів (A1A2 та A1A1). Це буде сприяти підтриманню бажаного рівня молочної продуктивності та якості молока.

Ключові слова: порода, молочна продуктивність, генотип, казеїн, вміст жиру, вміст білка

DOI: https://doi.org/10.32845/bsnau.lvst.2020.3.1

В Україні спільними зусиллями науки та бізнесу продовжується робота з подальшого підвищення рівня молочної продуктивності худоби. Одночасно приділяється увага його якісним показникам. Останнім часом науковці звертають увагу не лише на величину надою, жирність, білковість молока, а й на вміст конкретних фракцій казеїну, їхній різновид, технологічні якості під час переробки, вплив на харчову цінність продукту та здоров'я людини. У процесі досліджень вивчається вплив факторів навколишнього середовища та генотипу на мінливість складу молока. При цьому відмінності диференційовані у межах порід і окремих тварин [1].

Науковцями встановлено, що майже всі білкові фракції мають важливе та специфічне значення у різних фазах

процесу згортання молока під час технологічних процесів переробки. Доведено, що ця роль залежить від абсолютної кількості та відносної частки кожної фракції протеїнів незалежно від їхнього генетичного варіанту [2].

Зростання вимог до якості молочної продукції зумовили використання у селекції генетичних маркерів і пошук їхнього зв'язку із молочною продуктивністю тварин. У ситуації, що склалася, виникла необхідність зміни методів оцінки селекційних ознак тварин, нових підходів, заснованих на досягненнях генетики і біотехнології [3].

Саме тому одним із способів удосконалення якості молока, підвищення вмісту жиру та виробництва молочного 
білка є відбір тварин на основі молекулярних маркерів. Дослідники повідомляють, що ДНК поліморфні маркери дозволяють визначити окремі генотипи у багатьох локусах і забезпечити отримання інформації про параметри популяції, такі як алель та генетичні частоти. Їх можна використовувати як інструмент для вдосконалення відбору тварин [4].

При цьому науковці зазначають, що у випадку, якщо не досліджувати генотип молочної худоби і належним чином не обліковувати у програмі розведення, то існує ризик погіршення біохімічного складу молока. Це у свою чергу може призвести до зниження його придатності для переробки та виробництва різних молочних продуктів [1].

Наведені вище дані обумовлюють використання в програмах скотарства досліджень поліморфізму генів білків молока [6].

Зокрема дослідженням на поголів'ї голштинської худоби, було встановлено, що більшість локусів протеїну (бетаказеїн, капа-казеїн) мають потенціал для використання в якості маркерів генів у програмі відбору [6].

Існує 15 різних генетичних варіантів для бета-казеїну (A1, A2, A3, B, C, D, E, F, G, H1, H2, I, J, K, L). Серед них найбільш поширеними є варіанти A1, A2 та В. Бета-казеїн складається з 209 амінокислот, а референсним білком є алель А2. Варіанти відрізняються між собою однією або декількома різними амінокислотами в певних положеннях. Різниця між варіантами A1 і А2 становить лише одну амінокислоту - у положенні 67 - пролін у молоці А2 (дикий тип) та гістидин в молоці A1[7].

Бета-казеїн, що містить алель А1, при перетравленні у шлунку утворює полуку бета-казоморфін 7 (BCM 7), що чинить опіоїдну дію на організм. Вважається, що прийом цього алелю може спричинити алергію та інші захворювання людини. 3 іншого боку, алель А2 сприяє швидкому розкладу бета-казеїну на короткі пептидні ланцюжки, що не мають негативної дії на організм. Деякі породи корів мають більш високу експресію А2 бета-казеїну і виробляють менше алергенного молока. Такі факти сприяли ряду досліджень худоби різних порід в аспекті зустрічі різних генотипів за бета-казеїном $[8,10,11,12]$.

У той же час у практиків виникає питання, як впливає генотип тварин за бета-казеїном на показники молочної продуктивності. Подібні дослідження мало описані в літературі, що пов'язано з нещодавнім впровадженням виробництва молока A2A2 за бета-казеїном в окремих країнах світу. Так дослідниками було встановлено, що тварини з генотипом А1A1 мали менший вміст білка в молоці в порівнянні 3 тваринами генотипу A2A2 $[9,13,14]$.

Результати досліджень науковців, в яких вивчалося питання взаємозв'язку між генотипами бета-казеїну та особливостями молочної продуктивності дуже суперечливі. Автори Fürst, B., Schwarzenbacherб H. Wien [8] які систематизували їх за останні 25 років, цитуючи Ng-Kwai-Hang et al. (1984), зазначають, що встановлений позитивний вплив варіанту A2 порівняно з варіантом А1 на кількість молока у корів голштинської породи. За даними цих же авторів [8], Bech та Kristiansen (1990) довели, що генотип A2A2 порівняно з генотипом A1А1позитивно впливає на кількість білка в молоці у корів першої лактації і вміст жиру та білка у тварин другої лактації. За даними Ikonen et al. (1999), які наводять Fürst, B., Schwarzenbacherб H. Wien [8] тваринам з генотипом A2A2 характерні більший надій та вміст білка. Більший вміст жиру навпаки був характерний тваринам з генотипом А1А1. Отже, варіант А2 позитивно пов'язаний з більшою кількістю молока та білка, тоді як варіант А1 позитивно впливає на вміст жиру. Автори Fürst, B., Schwarzenbacherб H. Wien [8] також зазначають, що за результатами досліджень Heck et al. (2009), корови голштинської породи голандської селекції з варіантом А2 мали більшу молочну продуктивність білка, ніж у тварини 3 варіантом $A 1$.

У той же час автори Fürst, B., Schwarzenbacherб H. Wien [8] стверджують, що Olenski et al., (2010) встановили, що бугайці голштинської породи з генотипом А2А2 мають більшу селекційну цінність за надоєм та вмістом білка порівняно 3 тваринами генотипу $A 1 A 1$, але нижчу селекційну цінність за вмістом жиру. У той же час, науковці Fürst, B., Schwarzenbacher6 H. Wien [8] засвідчили, що в результаті досліджень. Kučerová et al. (2006) встановлено, що чеські бугаї симентальської породи з генотипом А2А2 мали негативну племінну оцінку, а тварини з генотипом A1A1 навпаки мали позитивну оцінку за величиною надою.

Що стосується придатності для виготовлення сиру, дослідники наводять результати досліджень Poulsen et al. (2013) згідно яких, молоко від тварин генотипу А2А2 мало значно більший час згортання та меншу стійкість гелю в у корів голштинської породи датської селекції порівняно з молоком від тварин генотипу А1А1. Варіант В мав значно коротший час згортання сиру та більш високу стійкість згустку, ніж варіант A1 [8].

Тому метою нашої роботи було - дослідити вплив генотипу корів за $\beta$-казїном на показники їх молочної продуктиBHOCTi.

Матеріали та методи досліджень. Дослідження проведені в Державному підприємстві «Дослідне господарство Інституту сільського господарства Північного Сходу НААН» Сумського району, Сумської області на поголів"ї корів української бурої молочної породи $(\mathrm{n}=28)$. Визначення поліморфізму гена бета-казеїну проводили в генетичній лабораторії Iнституту фізіології ім. Богомольця НАН. Надій визначали за щомісячними контрольними доїннями. Вміст жиру та білку в молоці визначали у лабораторії Інституту тваринництва НАAН на обладнанні фірми Bently.

Отримані результати обробляли методом варіаційної статистики за допомогою пакету програм Statistica 6,0.

Результати досліджень. В результаті проведених генетичних досліджень було встановлено, що у $43 \%$ корів був бажаний гомозиготний генотип A2A2. Більша частота (46\%) була характерна гетерозиготному генотипу A1A2. Частота гомозиготного генотипу A1A1 складала лише $11 \%$ (рис. 1). 


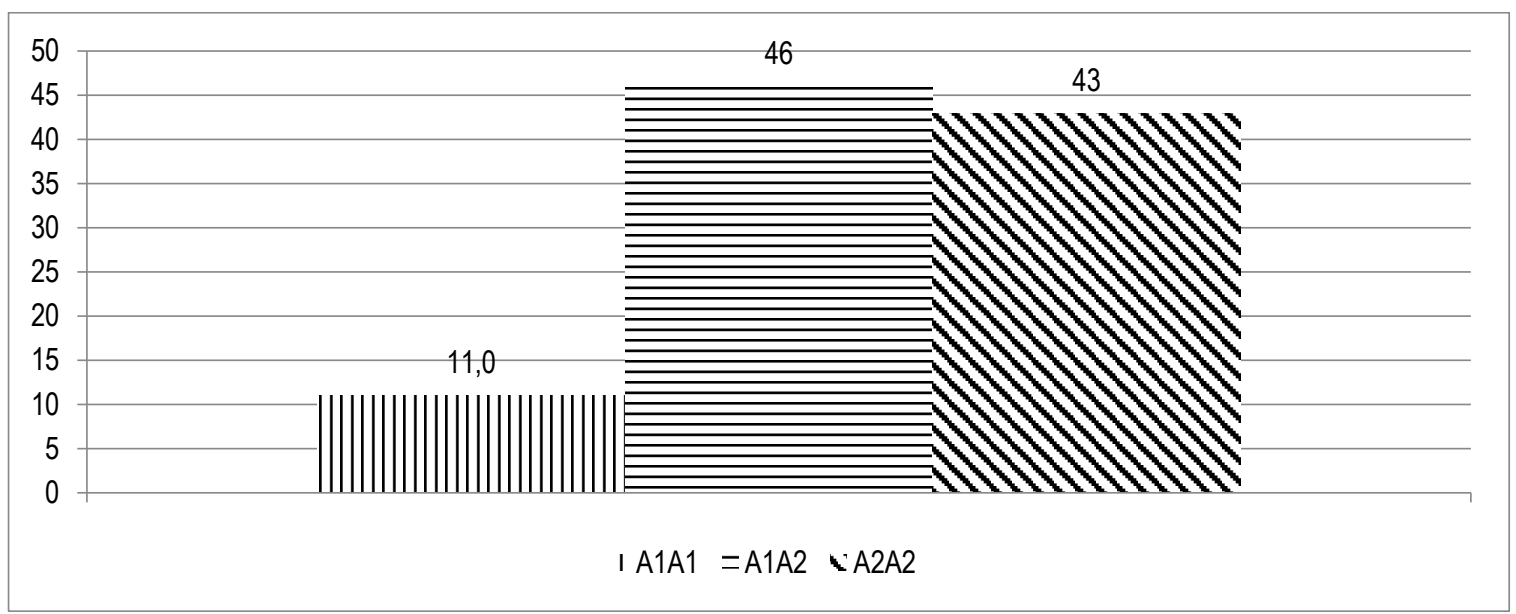

Рис. 1. Частота генотипів корів за геном $\beta$-казеїном, \%

Основним питанням щодо перспектив використання поліморфізму гену $\beta$-казеїну є вплив його на рівень молочної продуктивності корів. Поведені нами дослідження свідчать,

що тварини з бажаним генотипом А2A2 не поступаються за величиною надою тваринам 3 гетерозиготним генотипом A1A2 та гомозиготним - A1A1 (табл. 1).

Таблиця 1

Молочна продуктивність корів за першу лактацію залежно від генотипу за $\beta$-казеїном

\begin{tabular}{|c|c|c|c|c|c|c|}
\hline \multirow{2}{*}{ Генотипи } & \multirow{2}{*}{$\mathrm{n}$} & \multirow{2}{*}{ Надій, кг } & \multicolumn{2}{|c|}{ Вміст в молоці,\% } & \multicolumn{2}{|c|}{ Кількість. кг } \\
\cline { 4 - 7 } & & $5107 \pm 412,3$ & $4,15 \pm 0,171$ & $3,25 \pm 0,02$ & $217 \pm 13,1$ & $171 \pm 17,6$ \\
\hline А1А1 & 4 & $4889 \pm 304,9$ & $3,92 \pm 0,125$ & $3,15 \pm 0,036^{*}$ & $193 \pm 16,4$ & $153 \pm 11,1$ \\
\hline A1A2 & 16 & $5233 \pm 290,1$ & $3,61 \pm 0,126^{*}$ & $3,09 \pm 0,082$ & $189 \pm 16,4$ & $161 \pm 13,0$ \\
\hline A2A2 & 15 &
\end{tabular}

Хоча слід відмітити, що величиною надою достовірної різниці між тваринами різних генотипів не встановлено. При цьому за вмістом жиру в молоці гомозиготні А1A1 тварини переважали тварин з генотипом A2A2 (P<0,05, а за вмістом білка - тварин з генотипом A1A2 ( $<<0,05$.
Достовірної різниці за показниками молочної продуктивності по третій лактації не встановлено. Та відмічаємо також, що тварини бажаного генотипу A2A2 не поступалися за величиною надою та кількістю молочного білка тваринам різного генотипу (табл. 2).

Таблиця 2

Молочна продуктивнісь корів за третю лактацію залежно від генотипу за $\beta$-казеїном

\begin{tabular}{|c|c|c|c|c|c|c|}
\hline \multirow{2}{*}{ Генотипи } & \multirow{2}{*}{$\mathrm{n}$} & \multirow{2}{*}{ Надій, кг } & \multicolumn{2}{|c|}{ Вміст в молоці,\% } & \multicolumn{2}{|c|}{ Кількість. кг } \\
\hline & & & жиру & білка & молочного жиру & молочного білка \\
\hline A1A1 & 1 & 5110 & 4,06 & 3,21 & 212 & 164 \\
\hline $\mathrm{A} 1 \mathrm{~A} 2$ & 7 & $6049 \pm 637,2$ & $4,03 \pm 0,143$ & $3,16 \pm 0,034$ & $241 \pm 23,9$ & $191 \pm 25,1$ \\
\hline $\mathrm{A} 2 \mathrm{~A} 2$ & 8 & $6483 \pm 477,5$ & $3,83 \pm 0,235$ & $3,18 \pm 0,079$ & $212 \pm 42,9$ & $197 \pm 15,9$ \\
\hline
\end{tabular}

За показниками кращої лактації встановлена достовірна різниця за величиною надою між тваринами з генотипом A2A2 та A1A1 (на 35\% та A1A2 (на12\%. За вмістом жиру та білка в молоці достовірної різниці не встановлено. Хоча за вмістом жиру в молоці тварини з генотипом А2А2 поступалися тваринам з іншими досліджуваними генотипами, а за вмістом білка в молоці переважали їх (табл. 3).

Молочна продуктивність корів за кращу лактацію залежно від генотипу за $\beta$-казеїном

\begin{tabular}{|c|c|c|c|c|c|c|}
\hline \multirow{2}{*}{ Генотипи } & \multirow{2}{*}{$\mathrm{*}$} & Надій, кг & \multicolumn{2}{|c|}{ Вміст в молоці,\% } & \multicolumn{3}{|c|}{ Кількість. кг } \\
\cline { 4 - 7 } & & & жиру & білка & молочного жиру & молочного білка \\
\hline A1А1 & 4 & $5119 \pm 412,1^{*}$ & $4,15 \pm 0,171$ & $3,25 \pm 0,023$ & $217 \pm 13,1^{*}$ & $171 \pm 17,6^{*}$ \\
\hline A1A2 & 16 & $6198 \pm 288,3^{*}$ & $4,10 \pm 0,118$ & $3,18 \pm 0,061$ & $264 \pm 9,3^{*}$ & $210 \pm 12,6$ \\
\hline A2A2 & 15 & $6945 \pm 215,1^{*}$ & $4,02 \pm 0,096$ & $3,26 \pm 0,030$ & $285 \pm 15,5$ & $229 \pm 9,2$ \\
\hline
\end{tabular}

За кількістю молочного жиру та білка перевагу мали тварини з гомозиготним генотипом A2A2 за $\beta$-казеїну, які достовірно переважали тварин з генотипом A1A1.

Отримані результати співпадають з раніше проведеними нами дослідженнями, де ми стверджували, що використання бугаїв-плідників з генотипом A2A2 за бета-казеїном має покращувати господарсько-корисні ознаки нащадків, порівняно з бугаями інших генотипів (A2A1 та A1A1)[15]. Це сприятиме не лише отриманню тварин з бажаним генотипом, а й підтриманню бажаного рівня молочної продуктивності, якості молока, відтворної здатності та тривалості господарського використання корів. Із цією метою було проаналізовано бугаїв-плідників у каталозі бугаїв молочних і молочном'ясних порід для відтворення маточного поголів'я в 2020 році. Серед бугаїв-плідників статистично значущої різниці за надоєм між тваринами трьох досліджуваних генотипів за бета-казеїном не виявлено. За кількістю молочного жиру у дочок бугаїв з генотипом A2A2 переважали бугаїв з генотипом $\mathrm{A} 1 \mathrm{~A} 1(\mathrm{P}<0,01)$.

Висновки. У результаті проведеної роботи проаналізовані показники молочної продуктивності корів української 
бурої молочної породи в залежності від генотипу за бета-казеїном. Згідно даних генетичних досліджень встановлено, що у стаді бурої худоби дослідного господарства найчастіше зустрічаються тварини з генотипом А1А2 (46\%) та А2А2 (43\%). Показники молочної продуктивності худоби за всі досліджувані лактації вказують на те, що тварини з генотипом A2A2 не поступаються за величиною надою, кількістю молочного жиру та білка тваринам інших генотипів. За показниками кращої лактації гомозиготні корови з генотипом A2A2 переважали тварин інших генотипів за величиною надою, кількістю молочного жиру і білка.

\section{Список використаної літератури:}

1. Gustavsson F., Buitenhuis A., Johansson M., Bertelsen H., Glantz M., Poulsen N. Effects of breed and casein genetic variants on protein profile in milk from Swedish Red, Danish Holstein, and Danish Jersey cows. J. Dairy Sci. 2013. Vol. 97, P.38663877. DOI: http://dx.doi.org/ 10.3168/jds.2013-7312

2. Amalfitano N., Cipolat-Gotet C., Cecchinato A., Malacarne M., Summer A., Bittante G. Milk protein fractions strongly affect the patterns of coagulation, curd firming, and syneresis. J. Dairy Sci. 2018. Vol. 102, P.2903-2917. DOI: https://doi.org/10.3168/ids.2018-15524

3. Костюнина О. В. Молекулярная диагнстика генетического полиморфизма основных молочных белков и их связь с технологическими свойствами молока: автореф. дис. ... канд. біол. наук : 03.00.23. Дубровицы, 2005. 23 с.

4. Miluchová M., Gábor M., Candrák J., Trakovická A., Candráková K. Association of Hindlll-polymorphism in kappa-casein gene with milk, fat and protein yield in holstein cattle. Acta Biochimica Polonica. 2018. Vol. 65, No 3, P. 403-407. DOI: https: // doi. org/ 10. 18388 /abp. 20172313

5. Zepeda-Batista J., Saavedra-Jiménez A., Ruíz-Flores A., Núñez-Domínguez R., Ramírez-Valverde L. Potential influence of $\mathrm{k}$-casein and $\beta$-lactoglobulin genes in genetic association studies of milk quality traits. Asian-Australasian Journal of Animal Sciences. 2017. Vol. 30, No. 12, P. 1684-1688. DOI: https: // doi. org/ 10.5713/ajas.16.0481

6. Molee A., Poompramun C., Mernkrathoke P. Effect of casein genes - beta-LGB, DGAT1, GH, and LHR - on milk production and milk composition traits in crossbred Holsteins. Genetics and Molecular Research. 2015. Vol. 14, № 1, P. 2561-2571.

7. Fürst B., Schwarzenbacher H. Genetische Charakterisierung der Milcheiwei ß varianten beim Pinzgauer-Rind. Wien, 2018. 70 p.

8. Henrique do Nascimento Rangel A., Cavalcanti Sales D., Antas Urbano S., Geraldo Bezerra Galvãojúnior J., César de Andrade Neto J., de Souza Macêdo C. Lactose intolerance and cow's milk protein allergy. Food Science and Technology. 2016. Vol. 36(2), P. 179-187. http://dx.doi.org/http://dx.doi.org/10.1590/1678-457X.0019.

9. Heck J. M. L., Schennink A., van Valenberg H. J. F., Bovenhuis H., Visker M. H. P. W., van Arendonk J. A. M., van Hooijdonk A. C. M. Effects of milk protein variants on the protein composition of bovine milk. Journal of Dairy Science. 2009. Vol. 92, No. 3, P. 1192-1202. DOI:10.3168/jds.2008-1208.

10. Parashar A., Saini R. A1 milk and its controversy-areview. International Journal of Bioassays. 2015. Vol. 4., №12, P. 4611. 4619.

11. Кононова Л.В., Сычова О.В., Омарова Р.С. Необыкновенное коровье молоко. Молочная река. 2016. №3(63), С.62-

64. C.75-80.

12. Кузьменко Н.Б., Кузина А.Н. Роль бета-казеина в питании детей первых лет жизни. Лечащий врач. 2016. № 01/16,

13. Vallas M.,Kaart T.,Värv S., Pärna K., Jõudu I., Viinalass H., Pärna E. Composite $\beta$-K-casein genotypes and their effect on composition and coagulation of milk from Estonian Holstein cows. J. Dairy Sci. 2012. Vol. 95, P. 6760-6769. DOI: http://doi.org/ 10.3168/jds.2012-5495.

14. Ganguly, I., Kumar S., Gaur G., Singh U., Kumar A., Kumar S., Mann S., Sharma A., Status of $\beta$-casein (CSN2) Polymorphism in Frieswal (HF X Sahiwal Crossbred) Cattle. International Journal of Biotechnology and Bioengineering Research. 2013. Vol. 4, P. 6760-6769.

15. Ладика В. І., Скляренко Ю. І., Павленко Ю. М. Характеристика генетичної структури за геном ß-казеїну плідників, допущених до використання в Україні у 2020 році. Технологія виробництва та переробки продукції тварин. 2020. № 1, С. 39 45. DOI: https: // doi. org/10.33245/2310-9270-2020-157-1-39-45.

\section{References:}

1. Gustavsson, F., Buitenhuis, A., Johansson, M., Bertelsen, H., Glantz, M., and Poulsen, N., 2013. Effects of breed and casein genetic variants on protein profile in milk from Swedish Red, Danish Holstein, and Danish Jersey cows. J. Dairy Sci, issue 97, pp. 3866-3877.

2. Amalfitano, N., Cipolat-Gotet, C., Cecchinato, A., Malacarne, M., Summer, A. and Bittante, G., 2018. Milk protein fractions strongly affect the patterns of coagulation, curd firming, and syneresis. J. Dairy Sci., issue 102, pp. 2903-2917.

3. Kostyunina, O. V., 2005. Molekulyarnaya diagnstika geneticheskogo polimorfizma osnovny'kh molochny kh belkov $i$ ikh svyaz`s tekhnologicheskimi svojstvami moloka. Abstractof Ph. D. dissertation. Dubroviczy.

4. Miluchová, M., Gábor, M., Candrák, J., Trakovická, A. and Candráková, K., 2018. Association of Hindlll-polymorphism in kappa-casein gene with milk, fat and protein yield in holstein cattle. Acta Biochimica Polonica. issue 65, No 3, pp. $403-407$.

5. Zepeda-Batista, J., Saavedra-Jiménez, A., Ruíz-Flores, A., Núñez-Domínguez, R. and Ramírez-Valverde, L., 2017. Potential influence of $\mathrm{K}$-casein and $\beta$-lactoglobulin genes in genetic association studies of milk quality traits. Asian-Australasian Journal of Animal Sciences, issue. 30, No. 12, pp. 1684-1688. 
6. Molee, A., Poompramun, C. and Mernkrathoke P., 2015. Effect of casein genes - beta-LGB, DGAT1, GH, and LHR - on milk production and milk composition traits in crossbred Holsteins. Genetics and Molecular Research, issue 14, № 1, pp. 2561-2571.

7. Fürst, B., 2018. Schwarzenbacher, H. Genetische Charakterisierung der Milcheiwei ß varianten beim Pinzgauer-Rind. Wien.

8. Henrique do Nascimento Rangel, A., Cavalcanti Sales, D., Antas Urbano, S., Geraldo Bezerra Galvãojúnior, J., César de Andrade Neto, J. and de Souza Macêdo, C., 2016. Lactose intolerance and cow's milk protein allergy. Food Science and Technology, issue. 36(2), pp. 179-187.

9. Heck, J. M. L., Schennink, A., van Valenberg, H. J. F., Bovenhuis, H., Visker, M. H. P. W., van Arendonk, J. A. M. and van Hooijdonk, A. C. M., 2009. Effects of milk protein variants on the protein composition of bovine milk. Journal of Dairy Science. issue 92, No. 3, pp. 1192-1202.

10. Parashar, A. and Saini, R., 2015. A1 milk and its controversy-areview. International Journal of Bioassays. issue 4., №12, pp. 4611-4619.

11. Kononova, L.V., Sy'chova, O.V. and Omarova, R.S., 2016. Neoby'knovennoe korov'e moloko [Extraordinary cow's milk]. Molochnaya reka, issue 3(63), pp. 62-64.

12. Kuz 'menko, N.B. and Kuzina, A.N., 2016. Rol' beta-kazeina v pitanii detej pervy'kh let zhizni [The role of beta-casein in the nutrition of children in the first years of life]. Lechashhij vrach, issue 01/16, pp.75-80.

13. Vallas, M., Kaart T.,Värv, S., Pärna, K., Jõudu, I., Viinalass, H. and Pärna, E. Composite $\beta$-K-casein genotypes and their effect on composition and coagulation of milk from Estonian Holstein cows. J. Dairy Sci, issue 95, pp. 6760-6769.

14. Ganguly, I., Kumar, S., Gaur, G., Singh, U., Kumar, A., Kumar, S., Mann, S. and Sharma, A., 2013. Status of $\beta$-casein (CSN2) Polymorphism in Frieswal (HF X Sahiwal Crossbred) Cattle. International Journal of Biotechnology and Bioengineering Research, issue. 4, pp. 6760-6769.

15. Ladyka, V. I., Skliarenko, Yu. I. and Pavlenko Yu. M., 2020. Kharakterystyka henetychnoi struktury za henom $\beta$-kazeinu plidnykiv, dopushchenykh do vykorystannia v Ukraini u 2020 rotsi [Characteristics of the genetic structure of the $\beta$-casein gene of broods approved for use in Ukraine in 2020]. Tekhnolohiia vyrobnytstva ta pererobky produktsii tvaryn, issue 1, pp. 39-45.

Ladyka Volodymyr Ivanovych, Doctor of Agricultural Sciences, Professor, Academician of NAAS NAAS

Sklyarenko Yuriy Ivanovych, Doctor of Agricultural Sciences, Senior Researcher, Institute of Agriculture of Northern East of

Pavlenko Yuliya Mykolayivna, PhD of Agricultural Sciences, Docent, Sumy National Agrarian University

Malikova Alyona Ivanivna, graduate student, Sumy National Agrarian University

Comparative evaluation of dairy productivity of cows of ukrainian brown milk breed of different genotypes by $\beta$-casein

In recent years, the requirements for the quality of dairy products have significantly increased, which in turn requires the use of genetic markers in breeding and the search for their relationship with the milk productivity of animals. The study of the influence of the genotype of cows of the Ukrainian Brown dairy breed for $\beta$-casein on the indicators of their milk productivity was carried out in the Breeding Plant of the State Enterprise "Experimental Farm of Institute of Agriculture of Northern East of NAAS" of Sumy district, Sumy region on the livestock of the Ukrainian Brown dairy breed. The determination of the beta-casein gene polymorphism was carried out in the laboratory of Institute of Physiology named after Bogomolets of NAS. Milk productivity was determined by monthly control milking. The fat and protein content in milk was determined in the laboratory of Institute of Animal Husbandry of NAAS on Bently equipment.

Animals with genotypes A1A2 and A2A2 made up almost $90 \%$ of the studied livestock. Based on the results of our research, we found that animals with the desired A2A2 genotype are not inferior in milk yield to animals with heterozygous A1A2 genotype and homozygous A1A1 both in the first, third, and best lactation. According to the first and best lactation, animals with the A2A2 genotype were inferior in fat content to animals of other studied genotypes, but they were superior in protein content in milk. In terms of the amount of milk fat, cows with the desired A2A2 genotype were inferior to animals with other genotypes in the first lactation, but they were superior in terms of the amount of milk protein. In terms of the best lactation, animals with the A2A2 genotype outperformed others both in terms of the amount of milk fat and protein. The obtained results confirm our earlier results that the use of bulls-producers with the $\beta$-casein A2A2 genotype should improve the economically useful characteristics of offspring, compared to bulls of other genotypes (A2A1 and A1A1). This will help to maintain the desired level of milk productivity and milk quality.

Key words: breed, milk productivity, genotype, casein, fat content, protein content

Дата надходження до редакції: 02. 10.2020 р. 